University of Louisville

ThinkIR: The University of Louisville's Institutional Repository

\title{
The policy and personal motivations behind the endorsement of Donald Trump by four evangelical endorsers.
}

\author{
Benjamin F Hachten \\ University of Louisville
}

Follow this and additional works at: https://ir.library.louisville.edu/honors

Part of the Critical and Cultural Studies Commons, Journalism Studies Commons, and the Speech and Rhetorical Studies Commons

\section{Recommended Citation}

Hachten, Benjamin F, "The policy and personal motivations behind the endorsement of Donald Trump by four evangelical endorsers." (2017). College of Arts \& Sciences Senior Honors Theses. Paper 146.

http://doi.org/10.18297/honors/146

This Senior Honors Thesis is brought to you for free and open access by the College of Arts \& Sciences at ThinkIR: The University of Louisville's Institutional Repository. It has been accepted for inclusion in College of Arts \& Sciences Senior Honors Theses by an authorized administrator of ThinkIR: The University of Louisville's Institutional Repository. This title appears here courtesy of the author, who has retained all other copyrights. For more information, please contact thinkir@louisville.edu. 
The Policy and Personal Motivations Behind the Endorsement of Donald Trump by Four Evangelical Leaders

By

Ben Hachten

Submitted in partial fulfillment of the requirements

for Graduation summa cum laude

University of Louisville

May, 2017 


\section{Introduction}

In 2005, when Donald Trump was preparing for an appearance on Days of Our Lives, he engaged in what he would later call "locker room banter" with Billy Bush, the host of Access Hollywood. ${ }^{1}$ The banter was lewd and graphic; Trump said that he attempted to have sexual intercourse with a married woman and "moved on her like a bitch" while furniture shopping and that women will let you do "anything" when "you're a star," including grabbing their genitalia. ${ }^{2}$

The video of this exchange, The Washington Post received a month before Donald Trump would defeat Hillary Clinton to become the $45^{\text {th }}$ President of the United States, led to a rare apology from the Republican nominee. Immediately following the video’s release, 36 Republican lawmakers disavowed Trump's campaign, some going as far as to advise him to end his bid for office entirely and to let Mike Pence, his running mate, take over the Republican ticket. ${ }^{3}$ Even Pence condemned the words of the man who tapped him for Vice President: "As a husband and father, I was offended by the words and actions described by Donald Trump in the eleven-year-old video released yesterday. I do not condone his remarks and cannot defend them."4 The backlash Trump faced for his 2005 comments threatened to derail his hopes of winning the presidency by potentially costing him the votes of large numbers of critical demographics for Republicans, primarily women and socially conservative evangelical Christians. Of the latter category, Russell Moore, president of the Southern Baptists' Ethics and

\footnotetext{
${ }^{1}$ Fahrenthold, David. "Trump recorded having extremely lewd conversation about women in 2005." The Washington Post. 08 Oct. 2016.

2 "Transcript: Donald Trump's Taped Comments About Women." The New York Times. 08 Oct. 2016.

3 Blake, Aaron. "Three dozen Republicans have now called for Donald Trump to drop out." The Washington Post. 09 Oct. 2016.

${ }^{4}$ Hillyard, Vaughn. "Pence Cancels Event, Says He's 'Offended' by Trump Comments.” NBC News. 08 Oct. 2016.
} 
Religious Liberty Commission, denounced Trump's remarks about women and Albert Mohler, president of the Southern Baptist Theological Seminary in Louisville, tweeted that he was "humiliated" by some of the arguments evangelicals were making about character to justify Trump's comments following the tape's release..$^{5}$

This was not the first time that Moore and other well-known evangelicals had condemned Trump. In January of 2016 before Trump had been named the Republican nominee, Moore wrote an opinion piece for the conservative National Review entitled, "Donald Trump is Not the Moral Leader We Need." He questioned Trump's newfound commitment to pro-life initiatives and called much of Trump's rhetoric "racist," "sexist," and offensive to immigrants, women, and the disabled, rhetoric that Moore said should concern everyone who believes "all persons, not just the 'winners' of the moment, are created in God's image." Additionally, he argued that Trump's multiple marriages, sexual boasting and exploits, and involvement with and profit from the casino industry are indicative of a person unfit for moral leadership and undeserving of the conservative evangelical vote. ${ }^{6}$ These are disparaging words from one of the nation's most powerful evangelicals.

Similarly, in February, Max Lucado, a well-known Christian author, publicly criticized Trump's behavior and rhetoric, such as calling women "bimbos," his attitudes toward the disabled, and his inability to accept criticism without badmouthing the criticizer. ${ }^{7}$ Jim Wallis, the president and founder of the evangelical social justice magazine Sojourners criticized both

\footnotetext{
5 Pulliam Bailey, Sarah. "'Still the best candidate': Some evangelicals still back Trump despite lewd video." The Washington Post. 08 Oct. 2016.

${ }^{6}$ Moore, Russell. "Donald Trump is Not the Moral Leader We Need." National Review. 22 Jan. 2016.

${ }^{7}$ Kuruvilla, Carol. "Why These Evangelical Leaders Are Firmly Against Trump.” The Huffington Post. 22 July 2016.
} 
Trump and his evangelical supporters in a blog post published by The Huffington Post: "White evangelicals should have to explain, on the basis of their biblical faith... how they can feel comfortable with Trump's proposed policies of rounding up, deporting, and destroying the families of 11 million immigrants; killing the families of terrorists; restricting the religious liberty of Muslim citizens; banning Muslim refugees; and appealing to the worst and most dangerous instincts of white Americans." ${ }^{\prime 8}$ The list of evangelical leaders who denounced Trump throughout his campaign also included Peter Wehner, Senior Fellow at the Ethics and Public Policy Center, and Thabiti Anyabwile, conservative pastor and member of The Gospel Coalition. ${ }^{9}$ Additionally, nearly 100 evangelical leaders signed a letter published on Change.org urging their fellow evangelical Christians to vote against Trump (although they did not endorse Democratic candidate Hillary Clinton) and denouncing his campaign rhetoric as incompatible with the Christian faith:

Donald Trump's campaign is the most recent and extreme version of a history of racialized politics that has been pursued and about which white evangelicals, in particular, have been silent. The silence in previous times has set the environment for what we now see.

For this reason, we cannot ignore this bigotry, set it aside, just focus on other issues, or forget the things Mr. Trump has consistently said and done. No matter what other issues we also care about, we have to make it publicly clear that Mr. Trump's racial and religious bigotry and treatment of women is morally unacceptable to us as

\footnotetext{
${ }^{8}$ Wallis, Jim. "It's Embarrassing to Be an Evangelical This Election." The Huffington Post. 26 February 2016.

${ }^{9}$ Kurivilla, Carol. 22 July 2016.
} 
evangelical Christians, as we attempt to model Jesus' command to "love your neighbors as yourself. $^{10}$

The opposition that Donald Trump received from many leaders in the evangelical community might indicate that the group often known as "values voters" had finally found a Republican candidate they could not support. However, just as 78 percent of evangelicals voted for President George W. Bush in 2004, 74 percent voted for Senator John McCain in 2008, and 78 percent voted for Mitt Romney in 2012, 81 percent of white, evangelical Christians voted for Donald Trump in 2016, according to the Pew Research Center. ${ }^{11}$ Despite the denunciations of Trump by some religious leaders and the calls to action directed towards the evangelical community, the majority of evangelicals had motivations for supporting Trump other than what values voters would typically consider most important - character, religiosity, and social conservatism.

This paper examines the four prominent evangelical leaders - James Dobson, Mark Burns, Paula White and Jerry Falwell, Jr. - who endorsed Trump, continued to defend him, and encouraged their large followings to vote for the Republican nominee despite his lewd comments caught on tape, his multiple divorces, and his comments about women and minority groups, all of which are antithetical to the values held by evangelical Christians. In "Forum: Studying Religion in the Age of Trump," Randall Balmer argues that if leaders of the Religious Right were truly serious about promoting family values, their embrace of Trump defies reason. Balmer

\footnotetext{
10 "A Declaration by American Evangelicals Concerning Donald Trump." Change.org. https://www.change.org/p/donald-trump-a-declaration-by-american-evangelicals-concerningdonald-trump.

${ }^{11}$ Jessica Martínez and Gregory Smith. "How the faithful voted: A preliminary 2016 analysis." Pew Research Center. 09 Nov. 2016.
} 
poses this question: Why did evangelicals flock to Trump in the 2016 presidential election? ${ }^{12}$ My research aims to answer a similar question: What motivated James Dobson, Mark Burns, Paula White, and Jerry Falwell, Jr. to endorse Donald Trump while so many of their peers decided that Trump was not a candidate that evangelicals should support? In essence, I sought to find the rationales expressed by these four evangelical leaders that would override objections to Trump's morals. This study will show that, although many of Trump's actions and rhetoric were antithetical to evangelical values, the endorsers were motivated to endorse Trump based on his policy stances and personal qualifications and characteristics that were in line with their expressed preferences.

\section{Literature Review}

There is no literature on the motivations behind political endorsements by religious leaders; however, there is useful scholarship about celebrity endorsements, the leaders of the Religious Right, and voting behavior that explains the potential motivations of these four evangelicals and structures my interpretive framework. Like all political endorsements, celebrity endorsements intend to sway voters in the direction of a specific person and away from another. Most of the scholarship on political endorsements by celebrities up to this point is theoretical and focuses on the effects of the endorsements on voting behavior. However, Craig Garthwaite and Timothy Moore argue that beyond swaying public opinion, celebrity endorsements are driven by

\footnotetext{
${ }^{12}$ Randall Balmer, et al. "Forum: Studying Religion in the Age of Trump." Religion and Culture: A Journal of Interpretation. Vol. 27, Issue 1 (2017): 3-7.
} 
such personal motivations as a celebrity's political or interest group affiliations. ${ }^{13}$ Although the argument that a celebrity's personal motivations to endorse a candidate can encompass political ties is a good one, it does not explain why some celebrities who are not affiliated with political or interest groups suddenly become motivated to endorse political candidates. For example, when Oprah Winfrey endorsed Barack Obama for president in 2007, it was the first time she had publicly endorsed a candidate since she began her television show in 1986. The personal motivations of Winfrey were not necessarily related to her political affiliations and included her publicly stated belief that Obama's presidency would mean a "new level of consciousness" for the country and that Obama's personal characteristics were impressive. ${ }^{14}$ Oprah's endorsement reveals a gap between the current literature on celebrity endorsements and the expressed personal motivations for celebrities' endorsements of political candidates. Thomas Cronin and Michael Genovese argue that voters ultimately cast their ballot for the candidate they like the best and believe is the most qualified for office based on the issues being debated in a particular election. ${ }^{15}$ Then, endorsements might simply indicate that the candidate is liked by the endorser or that the endorser believes the candidate is the best person for the job. When combined, the literature on celebrity endorsements and voter behavior forms a more complete list of potential personal motivations for endorsing political candidates.

${ }^{13}$ Craig Garthwaite and Timothy Moore. "Can Celebrity Endorsements Affect Political Outcomes? Evidence from the 2008 US Democratic Presidential Primary." Journal of Law, Economics, and Organization. Vol. 29.2 (2012): 355-84.

14 "Why Oprah Endorsed Barack Obama." Oprah.com. http://www.oprah.com/world/why-oprahendorsed-barack-obama

15 Thomas Cronin and Michael Genovese. The Paradoxes of the American Presidency. Oxford: Oxford U Press, 2013. Print. 
The findings suggest that these evangelical Christian endorsers were motivated by their personal relationships with Trump and their claims that his personal qualifications made him the best candidate in this election. Not only were there references in support of Donald Trump's true character despite widespread criticism, but the contrast of Trump with his counterpart, Hillary Clinton, displayed their rationale for supporting the Republican nominee based on personal qualifications alone. Mark Burns publicly proclaimed that Trump's success as a businessman would enable him to spread health and wealth to all Americans; Paula White's personal relationship with Trump went back over a decade, and she spoke about the side of Trump of which the public was unaware; James Dobson stated on multiple occasions how terrified he was of Hillary Clinton and that Trump was the more qualified candidate; and, Jerry Falwell, Jr. called Trump a strong leader, cut from the same cloth as Winston Churchill. In summary, Trump's personal relationships with the endorsers and their preferences for his qualifications for office both motivated these four evangelical leaders to endorse him.

Scholarship related to the Religious Right and evangelical voting behavior points to two additional potential motivations for endorsing Trump. In God's Own Party: The Making of the Christian Right, David Williams posits that evangelicals have been involved in the political realm and active in socially conservative causes since the early twentieth century, but that their interest in partisan politics and support of Republican candidates became especially prominent in the 1980s following Ronald Reagan's campaign for president. Williams argues that the relationship between evangelicals and the Republican Party was forged by religious leaders involved in the culture wars of the 1960s and 1970s, such as Billy Graham and Jerry Falwell, Sr., who easily linked their political agenda to the Republican Party's policy platform. Since the 1980 election and the formation of the Moral Majority, evangelicals as a whole have supported 
Republican candidates in presidential elections and have constituted a key voter demographic for conservatives. For example, Republican President George W. Bush depended on evangelical voters for his election, and he continued to forge close relationships with leaders of the Religious Right throughout his tenure in the White House. ${ }^{16}$ The authors of "Religious Voting Blocs in the 1992 Election: The Year of the Evangelical" agree with Williams that the abrupt evangelical realignment can be traced back to Ronald Reagan's presidency. However, they add that the 1992 election was when evangelicals cemented themselves as the primary religious voting coalition for the Republican Party, as large numbers of mainline Protestants and white Catholics deserted the GOP and voted for Ross Perot or Bill Clinton. Additionally, the authors argued that the evangelical Protestant role in Republican electoral politics, while strong in 1992, had potential for considerable growth in future elections. ${ }^{17}$

Given the decades-old coalition between Republicans and evangelical leaders and the rates at which evangelical voters have voted for Republican candidates since the election of Ronald Reagan, I hypothesized that loyalty to the Grand Old Party would be a primary motivation for this group of evangelical Trump endorsers, allowing them to overlook the flaws of their candidate. However, this motivation appeared to be the least important for each of the endorsers. In fact, on multiple occasions Jerry Falwell, Jr. expressed his disdain for the Republican establishment that he felt caused many of the failed policies Trump vowed to correct. James Dobson shared Falwell's disdain for the GOP establishment, calling them traitors to

\footnotetext{
${ }^{16}$ Williams, Daniel. God's Own Party: The making of the Christian right. Oxford: Oxford U Press, 2010. Print.

${ }^{17}$ Lyman Kellstedt, et al. "Religious Voting Blocs in the 1992 Election: The Year of the Evangelical?" Sociology of Religion, Vol. 55, No. 3 (1994): 307-326.
} 
evangelical voters for their failure to pass socially conservative policies. Before this election, Mark Burns was a Democrat, and he voted for both Bill Clinton and Barack Obama in recent elections. Paula White was absent from the political realm altogether until Trump's rise into electoral politics. While support for the GOP was not explicitly referenced in their statements about why they supported Trump, it is possible that this motivation was still present under the surface or that it is more of an implied connection to the party's platform. The fact that Trump received 81 percent of the white evangelical vote suggests continuity in the pattern of evangelical support for Republican candidates.

Although loyalty to the Republican party was not explicit across the board, it alludes to another related concern: the policy influence that comes with political involvement and alliances with conservative politicians. Williams argues that evangelicals involved themselves in partisan politics in order to restore the nation's "Christian identity" and combat the teaching of evolution in schools, the increasing Catholic political influence, and the changing attitudes on gender and sexuality. Getting involved in the political process, specifically through their endorsements of and alliances with conservative politicians, enabled evangelicals to influence the nation's policy agenda and promote social conservativism on the national stage. ${ }^{18}$ Additionally, Jerry Falwell, Sr. founded the Moral Majority in 1979 with the primary goal of influencing public policy. As Doug Banwart points out in "Jerry Falwell, the Rise of the Moral Majority, and the 1980 Election," the Moral Majority was formed to address a host of "societal ills" through legislation. The political organization was involved in lobbying to end abortion, reinstate school prayer, and,

\footnotetext{
${ }^{18}$ Williams 2.
} 
in general, help the country "get back to its roots." ${ }^{\text {"19 }}$ Williams argues that despite a host of failed legislative measures that were intended to reclaim America as a Christian nation, evangelicals have continued to seek policy influence by campaigning and voting for socially conservative candidates. $^{20}$ The literature on evangelical leaders' desire to influence policy was supported by my findings, as this motivation for endorsing Donald Trump was the most important among the four evangelical leaders, all of whom expressed the desire to see conservative justices appointed to the Supreme Court.

The scholarship on evangelical voters tends to emphasize their preferences for moral issues, but there is evidence that the "moral values" of candidates do not top the list of important issues when evangelicals vote. In "Voters and Values in the 2004 Election," Gary Langer and Jon Cohen found that moral values were less important to evangelical voters than other issues of the 2004 election. ${ }^{21}$ Additionally, although economic issues are seldom considered the most salient issues for evangelicals, Thomas Carsey and Geoffrey Layman have found that economics has become a policy area that conservative Christians have adopted in recent years that coincides with their stance on social issues and identification with the Republican Party's policy platform. ${ }^{22}$ In "Conservative Protestantism in the United States? Toward a Comparative and Historical Perspective," Philip S. Gorski argues that partisan identification and policy interests have become intertwined for evangelicals and include a wide array of issues other than social

${ }^{19}$ Banwart, Doug. "Jerry Falwell, the Rise of the Moral Majority, and the 1980 Election." Western Illinois Historical Review, Vol. V (Spring 2013): 133-157.

${ }^{20}$ Williams 3.

${ }^{21}$ Gary Langer and Jon Cohen. "Voters and Values in the 2004 Election." The Public Opinion Quarterly, vol. 69, no. 5, 2005, pp. 744-759.

${ }_{22}$ Thomas Carsey and Geoffrey Layman. "Changing Sides or Changing Minds? Party Identification and Policy Preferences in the American Electorate." Blackwell Publishing, Inc. American Journal of Political Science, Volume 50, Issue 2 (April 2006): 464-477. 
policy. Additionally, voters tend to weigh their social values against their economic interests when deciding both their partisan affiliations and who to vote for in a particular election. Voters keep their material interests in mind when they vote their values, so it is not surprising that these endorsers would still value economic policy as well as social policy or a candidate's morals. ${ }^{23}$ This research on "values voters" helps explain why Trump's morals were not the most important issue for these evangelical leaders. For example, Burns and Falwell, Jr. were adamant that Trump's successful career as a businessman made him the only candidate who could lead the country in economic matters. When combined, the literature on the Religious Right and evangelical voting preferences provides a more holistic interpretive framework for analyzing the policy preferences of the four evangelical endorsers studied in this paper.

\section{Method}

I chose these four endorsers because they were all members of Trump's Evangelical Advisory Board but from different backgrounds. James Dobson and Jerry Falwell, Jr. are wellknown and influential members of the evangelical leadership class and have been involved in political causes throughout their careers, while Mark Burns and Paula White, televangelists and prosperity gospel preachers, made their political debuts this election cycle. It is not my intention to portray these four leaders as entirely representative of evangelicalism, and I make no causal connection between their endorsements and the high rate at which evangelicals voted for Trump. I analyze the rhetoric of each leader, who represents a swath of American evangelicals, to

\footnotetext{
${ }^{23}$ Gorski, Philip S. "Conservative Protestantism in the United States?: Toward a Comparative and Historical Perspective." Evangelicals and Democracy in America, Volume 1: Religion and Society, Edited by Steven Brint and Jean Reith Schroedel, Russell Sage Foundation (2009): 74 114.
} 
understand evangelicals' motivations for supporting Trump. To determine whether partisan, policy, or personal motivations were present, I examined written and oral statements by the endorsers that contained reasoning and justifications for supporting Donald Trump. I classified statements categorically based on explicit references to partisanship, policy or legislation preferences, and personal qualifications or characteristics. For example, a call for Republican unity would be classified under the partisanship category. Any statement expressing a preference for Supreme Court Justices would be classified under the policy or legislation category, and any reference to Trump's qualifications for office or other characteristics was classified under the personal qualifications or characteristics category. Written statements included op-eds the endorsers published, statements released on the endorsers' websites, and posts the endorsers made on their social media accounts. Oral communications included comments made at rallies or other public events, comments given to journalists, interviews with news outlets, and appearances on national television. What follows is a case-by-case analysis of statements made by James Dobson, Mark Burns, Paula White, and Jerry Falwell, Jr. I provide context for the endorsers' statements based on their personal backgrounds, past political involvement, and institutional or organizational ties to provide an understanding of the relationships between their public statements and their preferences. The contextual support came from a variety of sources: news coverage surrounding the endorsements or the endorsers, past endorsements and public statements by the four religious leaders, and mission statements or organizational values for the organizations that the endorsers have direct connections to. I took the endorsers' statements at face value, understanding that there may be alternative motivations for making a public statement of any kind, in order not to introduce extraneous interpretations of intention. In the conclusion, I interpret what these four endorsements mean within the larger context of the 
leadership of the Religious Right and the way in which scholars study the electoral motivations and behaviors of evangelicals.

\section{Cases}

\section{James Dobson}

Focus on the Family is a "global Christian ministry" that aims to provide resources to families and married couples to help them thrive. The non-profit's "Foundational Values" include the following:

We believe that all people are of infinite value, regardless of age, developments, appearance or ability; We believe that marriage is the foundation of family life, and that God's design for marriage is a relationship where both husband and wife are committed to loving and caring for one another for a lifetime; We believe children are a gift from God, and thrive best in a home where both mother and father are committed to raising them with love, intention, and care. ${ }^{24}$

Based on the expressed values of this socially conservative Christian organization, it is surprising that the group's founder and chairman emeritus, James Dobson, would endorse Donald Trump, whose disparaging comments about women and minorities contradict the belief that all people are of infinite value. Additionally, the fact that Trump has been married three times puts him at odds with the group's commitment to lifetime marriages, and his boasting about not doing anything to take care of his own children seems to go against the idea that children "thrive best in

${ }^{24}$ "Focus on the Family." About Focus on the Family. Focus on the Family. 
a home where both mother and father are committed to raising them." 25 But it is not just Focus on the Family's values that are at odds with much of what Trump says and does; Dobson's radio show, Family Talk, proclaims a focus on "preserving and promoting the institution of the family," marriage, parenthood, evangelism, the sanctity of human life and encouraging righteousness in the culture. ${ }^{26}$ Trump's divorces, his attitudes on parenting, his statement that he has never asked for forgiveness (a staple of evangelical Christianity), his comments that he would like to "take out" the presumably innocent families of terrorists, and his lewd comments about women contradict all of Dobson's stated organizational values. ${ }^{27}$

The New York Times called Dobson the nation's most influential leader in 2005 after his involvement in helping George W. Bush win re-election (his first time endorsing a candidate) and his subsequent activism in getting "strict constitutionalists" appointed to the Supreme Court. ${ }^{28}$ However, George W. Bush is hardly comparable to Donald Trump. Bush was, by all accounts, a born-again, evangelical Christian who overcame his drinking problem and saved his marriage, an oft-told story when he ran for public office. ${ }^{29}$ In other words, Bush was cut from the same cloth as the family-values evangelical, making Dobson's first foray into electoral politics understandable. What, then, led a man whose career has been dedicated to building stronger

25 Jeltsen, Melissa. Trump's Backwards Views On Parenting Could Have Disastrous Implications." The Huffington Post. 29 Jun. 2016.

26 "Family Talk Mission Statement." Dr. James Dobson's Family Talk.

${ }^{27}$ Scott, Eugene. "Trump believes in God, but hasn't sought forgiveness." CNN. 18 July 2015.; Ross, Ashley. "Donald Trump Says He'd 'Take Out' Terrorists' Families." TIME. 02 Dec. 2015. ${ }^{28}$ Kirkpatrick, David. "Evangelical Leader Threatens to Use His Political Muscle Against Some Democrats." The New York Times. 01 Jan. 2005.

${ }^{29}$ Wead, Doug. "The Spirituality of George W. Bush.” Frontline: The Jesus Factor. Public Broadcasting Station. 
marriages and families to endorse a candidate who has shown little regard for the institution of marriage?

At first glance, it may appear as if Dobson is simply a committed supporter of the Republican Party who pledged allegiance to Donald Trump, the Republican standard bearer, out of partisan loyalty. In 2004, he endorsed Bush and led the charge in defeating Senate minority leader Tom Daschle. In 2008, he endorsed the Republican nominee, John McCain, even after he had previously publicly disparaged McCain's character by calling him an unethical adulterer and comparing him to President Bill Clinton. ${ }^{30}$

However, Dobson's relationship with the Republican Party, particularly the party's establishment wing, has been tenuous at times. In 1996, Dobson voted for Howard Phillips, the United State Taxpayer Party's candidate and conservative Christian, instead of the Republican candidate, Bob Dole. Two years later, while speaking at a convention of conservative leaders in Arizona, Dobson stated that the Republican Congress was betraying conservative evangelical voters, and he threatened to abandon the Republican Party and take as many people with him as possible. ${ }^{31}$ More recently, in 2012, Dobson endorsed Rick Santorum, a conservative Christian, and never officially endorsed Mitt Romney after he defeated both Santorum and Newt Gingrich in the Republican primary. ${ }^{32}$ In an op-ed that was published in World Net Daily months before the 2012 election, Dobson claimed Romney was responsible for his own share of liberal policies and beliefs, citing Romney's statement that gays should be admitted to the Boy Scouts, and he

\footnotetext{
${ }^{30}$ Nickolas, Mark. "James Dobson Calls McCain An Unethical Adulterer, Compares Him To Bill Clinton." The Huffington Post. 20 Sept. 2008.

${ }^{31}$ Goodstein, Laurie. "Conservative Christian Leader Accuses Republicans of Betrayal." The New York Times. 12 Feb. 1998.

${ }^{32}$ Sonmez, Felicia. "Focus on Family founder James Dobson endorses Rick Santorum.” 19 Jan. 2012.
} 
advised Romney to talk about conservative social issues or else risk losing the election. ${ }^{33}$ Although Dobson did end up voting for Romney, primarily due to his distaste for Barack Obama and his respect for Romney's pro-life, pro-family running mate Paul Ryan, Dobson has displayed disillusionment with the Republican Party through its failures, in his opinion, to support and elect socially conservative candidates in presidential elections, as well as the lack of socially conservative legislation passed by Republican-controlled Congresses. On several occasions, he has endorsed "anti-establishment" candidates in presidential primaries such as Mike Huckabee, Rick Santorum, and Ted Cruz, and he has hesitated to endorse the party's standard bearer in the general election. Based on this evidence, the Republican Party does not seem to be an institution to which Dobson is unequivocally loyal. To him, it is more important that a candidate share his religious values and support pro-life, pro-family, and pro-religious freedom policies.

Character matters to Dobson, or so his track record would indicate. In September 1998, Dobson released a letter on behalf of Focus on the Family that disparaged then-President Bill Clinton for his extramarital affair while in office and his treatment of women. ${ }^{34}$ Almost 20 years later, Dobson endorsed Donald Trump, a man who has called women bimbos and bragged openly about his sexual conquests and attempts at groping women. Despite Dobson's earlier commitment to Ted Cruz and his appearance in an ad attacking Trump for his previous acceptance of the Supreme Court's ruling on gay marriage, he joined Trump's executive Evangelical Advisory Committee after Cruz lost in the primary and released a statement on his website in defense of Trump's newfound Christianity by saying, "If anything, this man is a baby

${ }^{33}$ Dobson, James. "Mitt Romney: Talk About Moral Issues... Or Lose.” WorldNetDaily. 15 Aug. 2012.

${ }^{34}$ Dobson, James. "From Dr. James Dobson - September 1998." 
Christian who doesn't have a clue about how believers think, talk and act.” A month later, Dobson released an official statement supporting the Republican nominee, only one day after Cruz was booed off the stage at the Republican National Convention for his refusal to endorse Trump. In the statement, he made several explicit statements in support of Donald Trump's personal characteristics: Dobson said that "he is the most capable candidate to lead the United States of America in this complicated hour" and that Trump's children speaking highly of their father was the tipping point for his endorsement: "As a psychologist and a family counselor, I have spent my life equipping and resourcing families. One thing I have observed is that you cannot make a child talk about his or her parents the way Donald Trump's children speak of him. That is one of a man's most significant affirmations." ${ }^{35}$ Although he later admitted that some evangelicals had reservations about voting for Trump, he stated that most of them have decided he was the best choice. "I believe it's a good choice. America needs strong and competent leadership," he said. From defending Trump as a baby Christian to labeling him a strong and competent leader to ultimately praising the man for his parenting, Dobson came a long way from attacking Trump in pro-Cruz ads. ${ }^{36}$ The evidence suggests that there is something more important to Dobson, a motivation that compelled him to overlook Trump's most damaging qualities and even his comments about women that Dobson called "deplorable." Immediately after he condemned the comments made by Trump in the released recording, he said, "I also find Hillary Clinton's support of partial birth abortion criminal and her opinion of evangelicals to be

${ }^{35}$ Smith, Samuel. "James Dobson Endorses Donald Trump for President." The Christian Post. 21 July 2016.

${ }^{36}$ Dobson, James. "Dr. James Dobson on Donald Trump's Christian Faith.” Drjamesdobson.org. Web. Accessed 30 Jan. 2017; Dias, Elizabeth. "James Dobson Endorses Donald Trump." TIME Magazine. 21 Jul. 2016. 
bigoted. There really is only one difference between the two. Mr. Trump promises to support religious liberty and the dignity of the unborn. Mrs. Clinton promises she will not." ${ }^{, 37}$ This comment alludes to Dobson's primary concern for the nation's policy agenda and provides insight into why he would endorse a candidate whose outward actions and values are antithetical to his career and life's work.

Dobson's endorsement was primarily driven by policy motivations and his desire to see the effects of Barack Obama's presidency erased from the country's memory. In fact, he even stated in an interview with Christianity Today that he does not hold partisan allegiances or candidates in high regard:

I don't vote for candidates or political parties. I support those who will lead the country righteously, honorably, and wisely. In many ways, this is a single-issue election because it will affect every dimension of American life: the makeup of the Supreme Court. Antonin Scalia's sudden death made this election the most significant of our lifetime. The next president will nominate perhaps three or more justices whose judicial philosophy will shape our country for generations to come. ${ }^{38}$

Dobson believed Trump's promise to appoint conservative Supreme Court Justices and to protect religious freedom. "I liked that he promised us emphatically that he will work to protect our religious liberties. He has since released a list of potential Supreme Court nominees that is stellar. We must pray that, if elected, he will keep his word.” While Dobson's concern over religious liberty is often vague, he claimed that Hillary Clinton will bring the "power of

\footnotetext{
${ }^{37}$ Pulliam Bailey, Sarah. "'We're all sinners': Jerry Falwell Jr Defends Donald Trump after video lewd remarks." The Washington Post. 10 Oct. 2016.

${ }^{38}$ Interview by CT Editors. "James Dobson: Why I Am Voting for Donald Trump." Christianity Today. 23 Sept. 2016.
} 
government" against people of faith, and that with the wrong president, the country could soon be facing a "massive assault" on religious liberty. As he explained how the wrong president could wage war on Christianity, he said the following:

Certain powerful groups and organizations seek to weaken the church of Jesus Christ and limit what pastors and ministers can say and do publicly. They believe some of our teachings represent "hate speech" and must be stifled. They seek to severely restrict the freedoms of Christian schools, nonprofit organizations, businesses, hospitals, charities, and seminaries. With Christian colleges and universities, they want to limit whom their leaders choose as professors and what their students will be taught. Government funding and accreditation will be in the crosshairs, and you can be sure that home schools will be targeted. $^{39}$

This interview with The Christian Post shows that policy matters to Dobson more than partisan loyalty or a candidate's character and values. Additionally, Dobson operates under the belief that Christianity is currently being threatened in the United States, which helps him to justify the means of ending the threat.

The importance he places on the Supreme Court is understandable, given the emphasis his organizations have placed on pro-life values and religious freedom, both of which he feels were under attack during Obama's tenure. Focus on the Family's website contains a number of resources for those trying to understand the social issues related to religious freedom and the sanctity of life, and Dobson speaks often on his desire to see a socially conservative agenda pushed on the national stage. ${ }^{40}$ However, it was surprising to some in the evangelical community

\footnotetext{
39 "James Dobson: Why I Am Voting for Donald Trump."

40 "Social Issues." Focus on the Family.
} 
that Dobson placed so much trust in Trump to enact a conservative policy agenda, particularly due to his past stances on abortion and his blatant disregard for the permanence of marriage. In response to being asked about this very point, Dobson defended Trump by saying, "Mr. Trump has been unwavering in his commitment to issues that are important to evangelicals such as myself. In particular, I have been heartened by his pledge to appoint conservative Supreme Court justices, preserve religious liberty, rebuild the military, and defend the sanctity of human life." When asked about Trump's support of pro-choice policies before he became a Republican presidential candidate, Dobson offered the following explanation: "On the issue of abortion, I choose not to evaluate him based on his past position but rather on what he says are his current convictions. I believe God can change the hearts and minds of people and I celebrate when they support principles of righteousness. ${ }^{41}$ In his October newsletter, he compared Donald Trump's pro-life stance to the policies he attributes to the Clintons:

Donald Trump hasn't vetoed bills that would have outlawed the procedure known as partial-birth abortion. Bill Clinton alone is responsible for the brains being sucked out of unanesthetized babies during delivery. That naziesque procedure continued for years until the Supreme Court declared it illegal. Donald Trump is pro-life. Clinton and his wife disrespect the Constitution of the United States, although Trump has promised to protect it, especially the First Amendment. Shall I go on? ${ }^{42}$

In an op-ed that was published on World Net Daily in August of 2016, Dobson wrote that in his first interaction with Trump in June of 2016, the candidate promised to repeal the "1954 tax-code amendment" that was offered by Lyndon B. Johnson, which prohibits tax-exempt organizations,

\footnotetext{
41 "James Dobson: Why I Am Voting for Donald Trump."

${ }^{42}$ Dobson, James. “Dr. Dobson's October Newsletter.” October 2016.
} 
including churches, from campaigning for political candidates. Dobson agrees with Trump's assertion that the "Johnson amendment" has limited freedom of "religious speech" by churches and non-profit organizations, and Trump's desire to repeal this specific piece of legislation reaffirmed Dobson's decision to endorse him. ${ }^{43}$

Righteousness, Dobson believes, can be accomplished only through legislation that promotes the sanctity of life and religious freedom and the appointment of strict constitutionalists to the Supreme Court. In his last newsletter before the election, he stated that the 2016 presidential election was about determining the great moral issues of our time and taking a stand for a righteous political agenda. He launched a Twitter campaign in the week leading up to the election, which championed the phrase "\#MyVoteMatters" accompanied by a statement about the sanctity of life, religious freedom, or traditional ("biblical") marriage (although, Trump did not oppose gay marriage during his campaign), encouraging his 45,000 Twitter followers to vote for a socially conservative agenda. ${ }^{44}$ Dobson's desire to see conservative policies signed into law predominated any other motivations he may have had for endorsing Trump and is the source of his public support and defense of the man he called a "baby Christian."

\section{Mark Burns}

Although the small-town televangelist had no political experience, Donald Trump picked Mark Burns to be a surrogate on the campaign trail. Most notably, the South Carolina pastor and

\footnotetext{
${ }^{43}$ Dobson, James. "My Battle With Christian Media About Trump." World Net Daily. 3 August 2016.

$44 @$ DrJamesCDobson. https://twitter.com/DrJamesCDobson.
} 
founder of the NOWNetwork, a web-based Christian programming network, delivered the controversial benediction at the Republican National Convention, which touted the Republican party as the "conservative party under God" and said Hillary Clinton and the liberal Democratic party were the real enemies. Interestingly, Burns went on to say that God gave Trump the words to unite the Republican Party and the country. ${ }^{45}$ Burns is a prosperity gospel preacher, someone who believes that God will bless believers with physical health and material wealth. ${ }^{46}$ He has no reservations about praying for prosperity, saying that Jesus never intended his followers to be broke. While the prosperity gospel movement is a sect of evangelicalism that is often controversial, even to the point of being deemed heretical by evangelical leaders like Russell Moore, president of the Southern Baptists' Ethics and Religious Liberty Commission, and Michael Horton, a theology professor at Westminster Seminary, Trump surrounded himself with prosperity pastors such as Burns and Paula White throughout his campaign. ${ }^{47}$

The economy of the American prosperity gospel has been fueled by ambition and a belief that material wealth is a result of God's favor. ${ }^{48}$ Then, it makes sense that Burns aligned himself with the billionaire mogul if he truly believed Trump would deliver on his promises to bring jobs and wealth back to America. Burns was pivotal to Trump's campaign and was responsible for reeling in the votes of religious African Americans, a group Burns sought to represent within the Republican Party. His attempts at mobilizing black voters to support Donald Trump were filled

\footnotetext{
45 "Pastor Mark Burns Gives Benediction at Republican National Convention in Cleveland." Youtube, uploaded by Right Side Broadcasting. 18 July 2016. https://www.youtube.com/watch? $\mathrm{v}=$ HruL3hLaAaU. ${ }^{46}$ Dias, Elizabeth. "Donald Trump's Prosperity Preachers." TIME Magazine.

${ }^{47}$ Horton, Michael. "Evangelicals should be deeply troubled by Donald Trump's attempt to mainstream heresy." The Washington Post. 3 Jan. 2017.

${ }^{48}$ Randall Balmer, et al., 11.
} 
with prophesying about the nation's future under God's chosen candidate and included appeals not to race but to money: "There is no black person, there is no white person, there is no yellow person, there is no red person, there's only green people! Green is money! Green are jobs!" he shouted as he opened up an Illinois rally for Trump in March. ${ }^{49}$ In this statement, the small-town pastor who believes God is responsible for his economic success provided an underlying motivation for supporting Trump despite the candidate's appeals to long-held racial prejudices: Trump's status as a billionaire and an emblem of the "American dream" coincide with Burns' beliefs in faith-based prosperity. Burns overlooked Trump's gaffes entirely, instead blaming the coverage of these gaffes on the media while simultaneously claiming that Trump is "fighting for Christianity." ${ }^{, 50}$ Potentially, one's moral behavior is of secondary importance to Burns, given his own trouble with telling the truth (in an interview with $C N N$ he admitted to lying about his credentials while applying for his first ministerial job), and because monetary success is his gauge for how much a person loves Jesus, he may have sincerely believed that he was campaigning for a man "that believes in the name of Jesus Christ!" when he encouraged rallyattenders in North Carolina to vote for the Republican candidate. ${ }^{51}$ Burns, unlike Dobson, was relatively unheard of in the political realm before he began his celebrity role as a surrogate for Trump, but he made his entry into electoral politics as exciting as it was polemic.

Before Burns delivered the highly partisan benediction at the Republican National Convention in July, he was a small-town pastor at the Harvest Praise and Worship Center in Easley, South Carolina. ${ }^{52}$ After previously living in section 8 housing and serving a stint in jail

\footnotetext{
${ }^{49}$ Dias, Elizabeth.

${ }^{50}$ Smith, Candace. "Meet the Pastors Who Support Donald Trump." ABC News. 14 April 2016.

${ }^{51}$ Tatum, Sophie. "Trump surrogate admits falsifying biographical claims.” CNN. 03 Sept. 2016.

${ }^{52}$ Smith, Candace. 14 April 2016.
} 
for a domestic violence assault charge, Burns turned his life around to become a pastor and the founder of NOWNetwork, which boasts over 11 million followers. ${ }^{53}$ Additionally, he was a longtime Democrat and voted for both Bill Clinton and Barack Obama. There is no documentation chronicling Burns' transition to the Republican Party, but since joining the Trump team, he has encouraged unity within the conservative movement. In his benediction, he called for unity in the "conservative party under God" and said that the enemy was not "other Republicans - but is Hillary Clinton and the Democratic Party." ${ }^{, 54}$ Those are strong words coming from a man who previously supported candidates from the party he now calls the enemy. Although Burns may not be a lifelong Republican loyalist, he played a major role in attempting to unite the fractured G.O.P. and encouraging voters, particularly African Americans, to leave the Democratic Party and support Donald Trump by arguing that the Democrats have failed African Americans for many years and care only about their votes. ${ }^{55}$ Furthermore, on multiple occasions, he said that he believes Christianity is "under attack" as a result of the Democratic Party's policies, even claiming the pro-choice movement is a plot by Democrats to destroy the next generation of African Americans. ${ }^{56}$ Although his transition into electoral politics was likely driven more by his personal relationship with Trump and his desire to see economic reform, the South Carolina pastor displayed the motivation to see his new party united against his old one.

Burns first met Trump in October 2015 at a widely covered meeting between the Republican candidate and a group of televangelists, an event organized by fellow prosperity

\footnotetext{
${ }^{53}$ Dias, Elizabeth.

54 "Pastor Mark Burns Gives Benediction at Republican National Convention in Cleveland."

55 Adler, Jerry. "16 People who shaped the 2016 election: Pastor Mark Burns." Yahoo News. 24 Oct. 2016.

${ }^{56}$ Novacic, Ines. "Why some African-American evangelicals are playing the Trump card." $C B S$ News. 19 Feb. 2016.
} 
preacher and TV personality Paula White. He was immediately impressed. Burns claimed the Holy Spirit told him that Trump was "legit" and revealed that the candidate was truthful. Despite receiving criticism from some members of his congregation, Burns endorsed the candidate and became a campaign surrogate for Trump a month after their first meeting. He has publicly defended many of Trump's comments, saying, "The facts point out that Mr. Trump is not a racist, not a bigot. He just says exactly what's on his mind, and people just aren't used to that.",57 Burns later said that Trump's track record as a businessman proves he is not a racist: "He's done business with literally almost every color and race, his work speaks volumes." 58

Burns felt a sense of personal allegiance to Trump and said he felt "appointed," much like Esther was appointed by Mordecai in the Bible, a statement he made in an interview with TIME magazine. ${ }^{59}$ In this interview, he said that his relationship with Trump was "good" and that they had a pastor-congregant type of friendship; he said that Donald Trump gave the "least likely people the opportunity to prove themselves" and that Trump was a leader who has overcome adversity and exuded born-again grace. Burns said that his relationship with Trump gave him unique insight about the man so many criticized for his unChristian rhetoric and actions: "I believe Donald Trump, not from what I've read in the paper, but in conversations, I've come to the conclusion that Trump has a personal relationship with God," Burns said when asked why he would throw his support behind a man who stated that he never asked God for forgiveness. He conceded that Trump is not a "perfect Christian" but that no one is. Burns said that God can use Trump "even with all of his shortcomings." 60

\footnotetext{
${ }^{57}$ Novacic, Ines. 19 Feb. 2016.

${ }^{58}$ Smith, Candace.14 April 2016.

${ }^{59}$ Elizabeth Dias and Diane Tsai. "Meet Donald Trump's Top Pastor.” TIME Magazine.

${ }^{60}$ Smith, Candace. 14 April 2016.
} 
In an interview with $C N N$ 's Victor Blackwell, Burns said he believes America is at a crossroads and requires a leader who can right the wrongs of establishment politics. He called Trump the "warrior," the "champion," and the "winner" that America needs to head in the right direction again. ${ }^{61}$ He even called Trump "the Winston Churchill of today" because of his willingness to fight ISIS and address racial division in the country. When asked about Trump's claims that African American communities are in the worst shape they have ever been, Burns again defended the candidate by saying that Trump addresses all voters as Americans instead of pandering for votes like Hillary Clinton. ${ }^{62}$ It is not clear how addressing all voters as “Americans" dispels the claim that Trump's rhetoric was never racist or, at the very least, divisive. Despite the fact that their friendship was only slightly older than a year, the emphasis Burns' preaching places on spiritual health and material wealth coincided with many of Trump's campaign messages, providing insight into Burns' primary motivation for endorsing Trump for president.

Despite Trump's comments chastising illegal immigrants, his inability to handle criticism without insulting his opponents, and his proposal to ban an entire religion from entering the United States, Burns said that Trump was the only candidate "fighting for Christianity." Trump shares the pastor's belief that "Christianity is under attack," and Burns cites Trump's claim that people do not say "Merry Christmas" anymore as a reason for supporting Trump, as well as the need to get back to the "core values" that made America great, presumably the Judeo-Christian values that Burns feels are currently lacking in the country. ${ }^{63}$

61 "Trump surrogate confronted about faked biographical claims." Youtube, uploaded by CNN. 3 Sept. 2016. https://www.youtube.com/watch?v=rbIGBCcfKZg.

62 Adler, Jerry. 24 Oct. 2016.

${ }^{63}$ Smith, Candace. 14 April 2016. 
It is not just Christian values that Burns feels are lacking. Jobs are important, too, and as Burns said, “It was never Jesus' intention for us to be broke.” Burns believes Trump represents not only a much needed spiritual renewal but economic success as well. It was Burns' belief that the policies of Trump would bring economic prosperity back to the country that drove his constant support of the man who was often at odds with many evangelical leaders. Despite backlash from conservative evangelicals like Russell Moore, Burns believed Trump's economic plans would help small towns across the country by bringing employment opportunities with companies like Microsoft to towns like Easley, South Carolina. ${ }^{64}$ Following a controversial tweet in which Burns forwarded a picture of Hillary Clinton in black face and accused the Clintons of "using” black voters, he defended his tweet, saying that Clinton pandered to African Americans to get their votes. Burns also said he understood African Americans' concerns about Trump but that the Republican nominee was committed to dealing with policy issues that affected minority Americans like "unemployment" and creating "better opportunities for all." "65 Additionally, national security is a key issue for Burns: "For me it's important that we protect our borders and our people. I'm a father of six children. I don't want to be fearful at McDonald's, and a car bomb goes off, or a San Bernardino attack takes place, whether in name of Jesus or Allah, it's all wrong." ${ }^{, 66}$ For Burns, Trump was the Churchillian leader who could defeat ISIS and prevent illegal immigrants from entering the country. Burns also believes liberal policies are responsible for not only the attack on Christianity but pro-choice abortion laws that "target" African

\footnotetext{
${ }^{64}$ Dias, Elizabeth.

65 "Pastor Mark Burns Defends Controversial Tweet." Meet the Press Daily, uploaded on 29 Aug. 2016. http://www.msnbc.com/mtp-daily/watch/pastor-mark-burns-defends-controversialtweet-753879107657.

${ }^{66}$ Novacic, Ines. 19 Feb. 2016.
} 
American women, although he failed to explain what he meant by this statement. ${ }^{67}$ Trump's promise to appoint strict constitutionalists to the Supreme Court likely would alleviate the concerns of pro-lifers like Burns whose concerns about policy changes have motivated them to stick by the Republican nominee despite his gaffes.

On the Christmas following Trump's victory, Burns tweeted that he was thankful for being able to utter the phrase "Merry Christmas" again. A week later, he tweeted praises for Trump's deal with Sprint that he claims brought back 5,000 jobs to the United States. Evidently, Burns believed that Trump had begun to deliver on his campaign promises, many of which were the basis for Burns' endorsement and role as a surrogate. ${ }^{68}$

\section{Paula White}

No one is more controversial within evangelical circles than the prosperity gospel preacher and millionaire minister, Paula White. Since beginning her ministry in the early 1990s, White has become a polarizing yet popular pastor and TV personality. The host of Paula Today has been featured on ABC's Good Morning America, CBN's 700 Club, MSNBC, and CNN. She has 15 books published and has received numerous awards for her humanitarian efforts across decades. ${ }^{69}$ Despite her humanitarian efforts and appearances on primetime television, White has been involved in a fair amount of controversy. In 2007, the United States Senate investigated White for the millions of dollars she had acquired from her television ministry, most of which she spent on airplanes and multimillion dollar properties. White, like Trump, is on her third

\footnotetext{
${ }^{67}$ Novacic, Ines. 19 Feb. 2016.

$68 @$ pastormarkburns. https://twitter.com/pastormarkburns.

69 “Awards and Endorsements." Paulawhite.org.
} 
marriage, another point of contention among evangelicals, most of whom believe that marriage is a lifetime commitment and that divorce is a sin against God. The Florida pastor has been called a heretic and a charlatan by fellow evangelical leaders, particularly for her teaching of the "feel good" gospel.

Donald Trump has come to White's defense saying, "She has a significant message to offer anyone who will tune in and pay attention." Although it is unclear what message Trump is referring to, Trump called her over a decade ago after watching several of her sermons on television. ${ }^{70}$ The two celebrities have a lot in common - multiple divorces, bankruptcy filings, a loyal following, and many critics among the professional establishment - so it is not surprising that Trump and White have developed a strong bond over the years, or that White would become Trump's main spiritual advisor on the campaign. In fact, White is credited with leading Trump to Christ, an evangelical practice that includes "discipling" people by informing them of the Gospel message until they profess to turn their lives over to Jesus. ${ }^{71}$ When asked about Trump's faith during an interview with Politico, White spoke with a specificity that many of his endorsers have avoided: "I can absolutely tell you that Mr. Trump has a relationship with God. He is a Christian, he accepts Jesus as his Lord and savior." These words hold serious importance among evangelicals; they are the words used to describe true believers, people who have turned over a new leaf and given themselves to Christ. However, many evangelical leaders do not think Trump is one of them, but then again, they do not know Donald Trump the way White knows Donald Trump. White's close relationship with Trump, rooted in their similar life experiences and roles

\footnotetext{
${ }^{70}$ Burke, Daniel. “Trump's spiritual adviser, Paula White, fires back at critics.” CNN. 5 Jan. 2017.

${ }^{71}$ Glueck, Katie. “Donald Trump’s God whisperer.” Politico. 11 July 2016.
} 
as celebrity figures, was the primary motivation for her endorsement of the Republican nominee, while policy issues were of secondary importance. Loyalty to the Republican Party was absent. White, like Trump, was new to GOP evangelical activism before the real estate mogul tapped her to be his main spiritual advisor. She was not well known by GOP leaders in her home state of Florida or at the national level. She had never been heavily involved in evangelical political causes, instead opting to carry out her ministry and humanitarian efforts removed from the political realm. ${ }^{72}$ Until 2011, when she brought a group of evangelical leaders together to discuss whether or not Trump should run for president in 2012, White had never involved herself or her ministry in the electoral politics of the evangelical establishment. Again, in September of 2015, she arranged a meeting between Trump and evangelical leaders as he sought religious endorsements and, ultimately, the Republican nomination. ${ }^{73}$ Her desire to stay out of politics would have likely been fulfilled had Trump not asked her for help in garnering evangelical support. After being tapped as Trump's spiritual advisor, White was essential in lining up endorsements and establishing Trump's evangelical advisory board, which included his three other evangelical endorsers: James Dobson, Mark Burns, and Jerry Falwell, Jr. She opened rallies and multiple prayer gatherings of televangelists in support of Trump in an attempt to unite the fractured Republican base, but her newfound activism was not due to her loyalty to the Republican Party or its causes but rather to her friend and confidant, Donald Trump. ${ }^{74}$

When it comes to public policy, White was quiet throughout her career. Until she was asked about Donald Trump's position on Planned Parenthood, she said relatively little about the

\footnotetext{
${ }_{73}^{72}$ Glueck, Katie. 11 July 2016.

${ }^{73}$ Kate Shellnutt and Sarah Eekhoff Zylstra. "Who's Who of Trump's 'Tremendous' Faith Advisers." Christianity Today. 22 June 2016.

${ }^{74}$ Glueck, Katie. 11 July 2016.
} 
policies Trump would champion, instead opting to talk about Trump's "generosity" or Christian faith. However, in an exclusive interview with The Christian Post, she supported Trump's prolife stance: "Mr. Trump is totally and entirely pro-life. He has acknowledged again and again his commitment to appoint pro-life Supreme Court Justices, and he's written an op-ed about his prolife position. He's even publicly released the list of justices he would appoint. People have a clear choice this election: a pro-life Donald Trump or a pro-choice Hillary Clinton." Later in the same interview, she indicated that the Supreme Court was important to her: "The next president will appoint between two and four Supreme Court justices, and that decision will preserve our country's values or it will fundamentally change America. This election is consequential.",75 Based on these statements, the Supreme Court appears to be the only policy issue of concern for White. However, it is not clear whether this issue was always important to her or if it was an attempt to garner evangelical support for her candidate and friend. Given her longtime silence on the policy issues, it is likely that her endorsement was motivated primarily by her friendship with the person she claims is a man of God.

Despite Trump's lewd comments about women and some of society's most vulnerable groups, White, who said she converted to Christianity at 18 years of age after being struck by Jesus' treatment of the "least of these," believes Donald Trump is a man who loves God and is hungry to grow in his faith. ${ }^{76}$ Many people, including James Dobson, believe White is responsible for converting Trump to Christianity and trust her sincerity when she speaks about his Christian faith. When asked if she led Trump to his faith in Christ, White said that although

\footnotetext{
${ }^{75}$ Nazworth, Napp. "Paula White on Donald Trump's Christian Faith (Exclusive Interview)." The Christian Post. 8 July 2016.

${ }^{76}$ Showalter, Brandon. "Paula White: Donald Trump More 'Hungry for God' Than People Know." The Christian Post. 15 Aug. 2016.
} 
she usually keeps her conversations and relationships with national leaders and celebrities confidential, she could assert with confidence that Trump verbally acknowledged his faith in Christ to her. Throughout the campaign cycle, Trump did not just struggle to act according to the tenets of the Christian faith, but he also committed several rhetorical gaffes when trying to identify with evangelicals: he could not name his favorite Bible verse when asked, he cited a verse that is not in the Bible on a different occasion, and he referred to Second Corinthians as “Two Corinthians.” Despite Trump's gaffes, White has continuously defended her friend's faith and said, "He's a Christian in the way that all Christians are, a work in progress." In an interview with Politico, she supported her claim that Trump is a Christian by telling stories of his generosity, especially to employees of the Trump organization; she claimed he is charitable and does not seek to be noticed for the many acts of kindness he does for the less fortunate. White, like Dobson, cited his children's praise of their father as another reason for supporting the candidate whose personal history does not coincide with the emphasis many evangelicals place on "family values." 77

It is not just his Christian faith or her friendship with Trump that motivated her to endorse and campaign for the Republican nominee. When asked why she supported Donald Trump for President, she said the following in the an interview with The Christian Post:

I know Donald Trump. I know the strong leader he is. I know how capable of a businessman he is. I know how compassionate he is. I know how smart he is. I know how he defends our values and the people whom he loves. I know how much he loves this country. I know how much he loves his children and how they admire and respect him.

\footnotetext{
${ }^{77}$ Nazworth, Napp. 8 July 2016.
} 
He didn't have to run for President. He did it because he loves America and he wants our future to be bright, and he's willing to fight for that. He's willing to sacrifice for it too. Despite constant attacks in the press and constant attempts to malign his character, countless phrases being taken out of context, and the loss of so much... he has decided it's worth it. $^{78}$

Based on this evidence, it is clear that White saw Trump as a capable and qualified candidate for President. Not only does she believe his successes as a businessman display his intelligence and leadership abilities, she believes that he loves America and is the type of leader the country needs to ensure peace and prosperity. Additionally, when addressing the doubts that many evangelicals had about trusting Trump to enact a conservative agenda, White said, "Some people embrace this idea that we have to trust him because he's better than the alternative. Well, I don't believe that's true. I think we can legitimately trust him." ${ }^{\text {79 }}$ The evidence points to White's respect for and relationship with the polarizing candidate as the primary motivation for her initial endorsement and subsequent role in the campaign.

Following Trump's victory in the November election, he picked White, along with several other evangelical leaders, to pray at his inauguration in January 2017. Even this move was seen as controversial, with many evangelical leaders calling White a heretic and a Trinitydenier, a reference to her controversial theological teachings. The pastor of New Destiny Christian center delivered the inauguration's invocation, in which she prayed for Donald Trump

\footnotetext{
${ }^{78}$ Nazworth, Napp. 8 July 2016.

${ }^{79}$ Nazworth, Napp. 8 July 2016.
} 
and asked God for the "grace to unify" the country and the "strength to stand for what is honorable and right. ${ }^{.80}$

\section{Jerry Falwell, Jr.}

Following the October 2016 release of the controversial video from 2005, in which Trump was recorded saying lewd and derogatory things about women, a group of Liberty University students released a petition, "Liberty United Against Trump," which denounced not only the Republican nominee but the endorsement of him by the university's president, Jerry Falwell, Jr. The statement criticized Falwell's involvement in the Trump campaign and lamented that their beloved university had been associated with a man who made his name "by maligning others and bragging about his sins" and actively promoted behavior that Christians should oppose. The statement went on to say that although any faculty or staff member at Liberty would be terminated for comments like Trump's on the released tape, Falwell rushed to the defense of Trump. Students were asked to sign their name to the petition to denounce Trump and his association with Liberty University. ${ }^{81}$ Only a few days after the statement was released, over 2,000 students and faculty had signed the statement.

The three students behind the statement, Dustin Wahl, Paige Cutler, and Alexander Forbes, later published an op-ed in The Washington Post entitled, "Liberty University students: Trump is the antithesis of Christian values," which expressed their opposition to President Falwell's endorsement of Trump and their president's refusal to let Liberty faculty and staff

\footnotetext{
80 "Invocation by Pastor Paula White." CNN. 20 Jan. 2017.

81 "Liberty United Against Trump." https://docs.google.com/forms/d/e/1FAIpQLScdLe5fbVw0d12MtiYcJCfhLDjpr7AdiYTIkMBttqdLuTQbg/viewform.
} 
publicly criticize the Republican nominee. Wahl, Cutler, and Forbes said they understood that many Christians feared that a Hillary Clinton presidency would threaten religious freedom, but that supporting and trusting Trump to appoint conservative Supreme Court Justices despite changing his position on many important issues was not the solution. The students ended with a call to action: "Trump is the antithesis of our values; there is no reason to revisit his vices here. Most non-Christians recognize Trump as amoral and self-centered. If we ignore this fact and buy in to his promise of strength, what will it tell the world about how seriously we Christians esteem our values?" 82 Despite the backlash Falwell, Jr. received from students and faculty at the flagship evangelical university that his father, Jerry Falwell, Sr., founded, the school's president stuck by his January 2016 endorsement of Trump and continued to defend the Republican nominee. Although Falwell admitted that there was "nothing defensible" about Trump's comments about women, he justified his continued support of Trump by saying that, "We're all sinners," and adding that the only "perfect candidate" would be Jesus Christ. ${ }^{83}$

Falwell's endorsement and campaign efforts on behalf of the Republican nominee not only divided his students but brought him into the political spotlight as well. Falwell is the most famous of Trump's evangelical endorsers; his father, a titan of Christian conservatism, founded the Moral Majority that emphasized ethics and Judeo-Christian values in politics. Over 127,000 students take courses at Liberty University, both online and on campus, making it the largest Christian university in the world. In short, his influence is widespread, especially within

\footnotetext{
${ }^{82}$ Paige Cutler, Alexander Forbes, and Dustin Wahl. "Liberty University students: Trump is the antithesis of Christian values.” The Washington Post. 25 Oct. 2016.

${ }^{83}$ Falwell, Jr., Jerry. "Jerry Falwell Jr.: Trump is the Churchillian leader we need." The Washington Post. 19 Aug. 2016.
} 
mainstream evangelicalism. ${ }^{84}$ Unsurprisingly, Falwell is no stranger to electoral politics and has invited presidential candidates from all ends of the political spectrum to talk at Liberty, from Bernie Sanders to Ted Cruz. ${ }^{85}$ Additionally, he is no stranger to controversial stances, as he once encouraged his students to "take up arms" to deter terrorist attacks while referencing the pistol in his back pocket. ${ }^{86}$ However, he has never done anything as polarizing as endorsing Donald Trump for President of the United States. Seemingly, there are several issues of importance to Falwell that outweigh Trump's "sins" and motivated his continued support of a candidate who many Liberty students claimed is the antithesis of Christianity.

Although Jerry Falwell, Sr. was largely responsible for the Republican Party's alliance with the evangelical voting bloc, his son has been antagonistic towards the GOP establishment in recent times. In an interview with the Liberty Champion, Liberty University's student newspaper, Falwell acknowledged that in the past, evangelical voters would vote only for a candidate who shared their religious values, but that years of betrayal by establishment Republicans who claimed to be socially and fiscally conservative have led evangelicals to want someone who has "succeeded in the private sector, not just someone who makes the right promises in speeches. ${ }^{" 87}$ Early in 2016, in an op-ed published in The Washington Post, Falwell, Jr. blamed "weak establishment Republicans" for Democratic wins in 2008 and 2012 and voiced his support for Trump by saying, "Donald Trump is not another establishment Republican.” He

\footnotetext{
${ }^{84}$ Ambrosino, Brandon. "How Trump is Dividing Jerry Falwell's University." Politico. 27 Oct. 2016.

${ }^{85}$ Corasaniti, Nick. "Bernie Sanders Makes Rare Appeal to Evangelicals at Liberty University." The New York Times. 14 Sept. 2015.; David Fahrenthold and Katie Zezima. "Ted Cruz: 'I am running for president of the United States'.” The Washington Post. 23 Mar. 2015. ${ }^{86}$ Anderson, Nick. "For Many at Liberty University, Guns and God Go Hand in Hand." The Washington Post. 14 Dec. 2015.

${ }^{87}$ Rodriguez, Sarah. "Falwell Speaks.” Liberty Champion. 8 Mar. 2016.
} 
not only blamed the policies of President Obama and Secretary of State Hillary Clinton for the rise of Islamic terrorism since 2008, he claimed that a "feckless establishment Republican Congress" enabled these policies to be enacted. ${ }^{88}$ Following the release of the recording that was predicted to dismantle Trump's campaign just a month before the election, Falwell claimed, in comments made on WABC Radio in New York City, that GOP establishment leaders had conspired to release the tape and take down Trump's campaign: "I think this whole videotape thing was planned, I think it was timed, I think it might have even been a conspiracy among the establishment Republicans who've known about it for weeks and who tried to time it to do the maximum damage to Donald Trump." He even went as far as to say House Speaker Paul Ryan was behind the video's release, because it gave him a reason to disinvite Trump from an election rally the two were supposed to appear at together. ${ }^{89}$ Falwell's remarks show little regard for loyalty to the Republican Party, particularly its establishment leadership, despite his conservative alignment on policy issues, ranging from gun rights to abortion. It is not surprising that Falwell would form a strong political relationship with the anti-establishment candidate.

Over the course of several months leading up to Falwell's January 2016 endorsement of Donald Trump, the two friends began exchanging private phone calls. Falwell began publicly encouraging Trump and even went as far as to say that Trump reminded him of his father, Jerry Falwell, Sr. ${ }^{90}$ In an interview with the Liberty Champion, Falwell said that much of his

\footnotetext{
${ }^{88}$ Falwell, Jr., Jerry. “Jerry Falwell Jr: Here's the backstory of why I endorsed Donald Trump." The Washington Post. 27 Jan. 2016.

${ }^{89}$ Pulliam Bailey, Sarah. 10 Oct. 2016.

${ }^{90}$ Robert Costa and Jenna Johnston. "Evangelical leader Jerry Falwell Jr. endorses Trump." The Washington Post. 26 Jan. 2016.
} 
endorsement had to do with Trump's business experiences and their shared experiences as young business leaders attempting to save their respective business dealings from going bankrupt:

He doesn't need the money. He's paying for his own campaign. He's not beholden to anybody like the rest of them are. He's made a payroll with tens of thousands of employees, and nobody else on that debate stage has ever made a payroll and never will. They don't understand it. They don't know what it's like to be a businessman who is trying to survive or a businesswoman who is trying to make it. Trump does. I come at it from a unique perspective because I've been through experiences that most people haven't. Keeping a school afloat for 20 years was my job as a young lawyer. I know what it takes, and I want somebody who's done that ${ }^{91}$.

In Falwell's speech at the 2016 Republican National Convention, he cited Trump as "one of the greatest visionaries of our time" and that his role in creating jobs for thousands was a primary reason he supported the candidate. ${ }^{92}$ In his first Washington Post op-ed, he expressed the qualities he looks for in a President, qualities that many "career politicians" lack: "In my opinion, this nation needs a citizen legislator who is a tough negotiator, one who has gone head to head with the best business minds in the world and won, a businessman who has built companies from the ground up, and who will use those experiences to be tough with China, ISIS and nations that are taking advantage of the United States by stealing our jobs." Additionally, he said that it is more important to elect a strong leader who can prevent the nation from going bankrupt than one whose values are in line with evangelicals, and he cited his father's support

\footnotetext{
${ }^{91}$ Rodriguez, Sarah. 8 Mar. 2016.

92 "Full Speech: Jerry Falwell, Jr. Speaks at Republican National Convention." Youtube, uploaded by Right Side Broadcasting. 21 July 2016. https://www.youtube.com/watch?v=VYz_Zyg7uGI.
} 
for Ronald Reagan, a divorced Hollywood star, as evidence that America does not need a "Sunday School teacher" but a businessman. ${ }^{93}$ In August, the Liberty University president wrote another op-ed in The Washington Post comparing Trump's leadership abilities to those of Winston Churchill: "We are at a crossroads where our first priority must be saving our nation. We need a leader with qualities that resemble those of Winston Churchill, and I believe that leader is Donald Trump. As Churchill did, Trump possesses the resolve to put his country first and to never give up in a world that is increasingly hostile to our values." He called Trump a "strong leader" and "one who is not afraid to call the enemy by its name and to take the battle to that enemy if necessary." It is interesting that "strong" leadership is more important to Falwell than electing a leader who shares his religious or social values, and he was the most outspoken about this point out of the four endorsers analyzed in this paper. ${ }^{94}$

Not only did Falwell claim that Trump would provide bold and fresh leadership, he believed, based on his friendship with Trump dating back to 2012 that he was a "changed" man, one who would no longer brag about his sexual exploits. ${ }^{95} \mathrm{He}$ said he came to admire Trump as a father, as someone who is generous to those in need, and as an ethical and honest businessman. Falwell stated that his family loved all of the Trumps, who were "wonderful people willing to sacrifice much for their country." He claimed that much of the "false" public perception of Trump has been created by the media and that Trump is instead a man who is kind, generous, and willing to give up his business successes to help ordinary Americans. ${ }^{96}$ When asked about

\footnotetext{
${ }^{93}$ Falwell, Jr., Jerry. 27 Jan. 2016.

${ }^{94}$ Falwell, Jr. 27 Jan. 2016.

95 "Falwell Jr.: I'm voting for Trump, despite allegations." CNN. http://www.cnn.com/videos/politics/2016/10/13/jerry-falwell-jr-vote-for-trump-sot-erin.cnn. ${ }^{96}$ Falwell, Jr., Jerry. 19 Aug. 2016.
} 
some of the more derogatory comments made by Trump on the campaign trail, Falwell said, "He is not part of the establishment. He's been a businessman all his life, an entrepreneur. He's not a career politician. He hasn't been groomed to say all the right things to all the right crowds to get their votes. He's just himself." In this same interview, he called Trump a "wonderful father and a man who I believe can lead our country to greatness again." 97 These attempts to humanize the man that many evangelicals denounced were likely motivated by Falwell's friendship with Trump, and it remains probable that the primary motivation for Falwell's endorsement of Trump was the importance he placed on strong leadership, which he felt has been lacking in recent years. Falwell also believed that Donald Trump would enact a conservative policy agenda, an additional motivation behind his endorsement.

In Falwell's speech at the Republican National Convention, he touted Trump's "plank" to the Republican Party's platform to repeal the rules put in place under Lyndon Johnson that prevent tax exempt organizations, like churches, from campaigning for political candidates. He went on to say that this repeal of the "Johnson Amendment" would return free speech to churches and conservative universities, both of which he claimed were unfairly targeted by the Internal Revenue Service. ${ }^{98}$ A staunch supporter of gun rights, Falwell claimed that if Clinton were elected, the "right to bear arms would be effectively lost" and that activist judges would rewrite the constitution "in ways that would make it unrecognizable to our founders." With liberal justices on the Supreme Court, Falwell said you can "say goodbye to the Second Amendment" and that if Christians stayed home or supported another candidate, they would be forced to live in a country that they would not be able to recognize. He said that a vote for

\footnotetext{
${ }^{97}$ Rodriguez, Sarah. 8 Mar. 2016.

98 "Full Speech: Jerry Falwell, Jr. Speaks at Republican National Convention."
} 
Donald Trump was a vote for "more freedom and less government, a vote for national security and responsible immigration policy, a vote to finally fight radical Islamic terrorism. It is a vote to rebuild America's respect overseas and a vote for strict-constructionist and pro-life Supreme Court justices." Falwell also talked about the national debt: "With $\$ 20$ trillion in debt, we're right on the edge of the abyss and if we don't make some big changes, we're going right down the hole." 99 When he defended Trump's "dumb" comments about women in October 2016, he said that no one would care about what Trump said 11 years ago when our nation's economy went down the "toilet" or when the Supreme Court was "stacked with liberals who don't honor the Constitution." 100 Although, like many evangelical leaders, Falwell cares about social issues, it is apparent that he is also concerned with broader policy issues such as the economy, national security, and the Second Amendment: "All the other issues will be moot if we don't save the country," said Falwell, and in his opinion, Trump was best suited to "save" and "restore" America. $^{101}$

In an appearance on Fox News Sunday after the election, Falwell was understandably excited that his candidate won the presidency and said he believed there is a "new hope" and a "good spirit" in America. He said Trump's platform resonated with evangelical voters, who supported Trump in historic numbers, despite his behavior and rhetoric that many evangelical leaders deemed antithetical to Christianity. ${ }^{102}$ After Trump's election to the nation's highest

\footnotetext{
${ }^{99}$ Falwell, Jr., Jerry. 19 Aug. 2016.

${ }^{100}$ Pulliam Bailey, Sarah. 10 Oct. 2016.

${ }^{101}$ Rodriguez, Sarah. 8 Mar. 2016.

${ }^{102}$ Fox News Sunday, uploaded on 25 Dec. 2016.

https://www.facebook.com/FoxNewsSunday/videos/10153551710887168/.
} 
office, Falwell planned to open a high-tech shooting range on Liberty's campus, as part of the school's "pro-Second Amendment” and gun-friendly efforts. ${ }^{103}$

\section{Conclusion}

Donald Trump won more evangelical votes than Republicans George W. Bush, John McCain, or Mitt Romney, which shows that it was not just Trump's evangelical endorsers who supported the candidate despite what appeared to be the many differences between Trump's rhetoric and actions and his supporters' beliefs and values. The rhetorical evidence from this paper suggests that these endorsers, much like evangelical voters, were concerned with a broad set of issues, including the nation's policy agenda and the leadership qualifications and personal characteristics of their candidates. That is, moral issues, while important to evangelicals, are not the only factor in their decision to support a candidate. Although many evangelical leaders questioned the character and integrity of Trump, the support he garnered from these four prominent evangelical leaders suggests that the coalition between Religious Right leaders and Republican presidential candidates has not been broken. However, this election has also highlighted a potential schism within the evangelical leadership.

Much of the literature on the Religious Right focuses on how leaders have formed coalitions with Republican politicians to garner policy influence since Jerry Falwell, Sr. founded the Moral Majority in the late 1970s. Additionally, the scholarship suggests that evangelical leaders focus on pro-life policies, religious freedom laws, and other moral issues. In fact, policy issues were of central importance to the endorsers analyzed in this paper, as there were a total of

\footnotetext{
${ }^{103}$ Shapiro, T. Rees. "Gun-friendly Liberty University to open on-campus shooting range." The Washington Post. 15 Dec. 2016.
} 
32 references to policy preferences in their public statements. ${ }^{104}$ Additionally, appointments to the Supreme Court were explicitly referenced by all four endorsers. The endorsers reflected a more diverse preference set that scholarship on religious leaders does not currently acknowledge. For example, national security, immigration, and the economy were explicitly expressed as issues of importance to two of the endorsers. While literature on evangelical voters has begun to look at the wider range of issues important to this key voting bloc, the issues of importance for the leaders of this movement are rarely taken into account.

There is evidence to suggest that many voters simply cast their ballot for the candidate that they like the most or believe is the most qualified for office. The idea that endorsers, particularly celebrities, could endorse a candidate for personal reasons, such as a friendship with a politician or a respect for a candidate's leadership characteristics, is a new one. Collectively, these four endorsers expressed personal motivations for endorsing Trump 38 times, which indicates that they looked past some of the moral issues of his campaign to personal qualifications and characteristics that they felt made Trump the best candidate in this election. Interestingly, Paula White expressed personal motivations for endorsing Trump nine times compared to only two references to policy motivations, making her endorsement the most personal of the four endorsers.

The importance that the endorsers placed on both policy preferences and the qualifications and characteristics of Trump suggest that these four endorsers considered a broad set of factors when deciding to support Trump for President. Most evangelical voters are not single-issue voters, and the rhetorical evidence of this paper suggests that evangelical endorsers

${ }^{104}$ See Appendix for all data used in the conclusion. 
are not, either. Although many evangelical leaders criticized Trump for his rhetoric and his issues with morality, it was evident that he had much in common with those who endorsed him (from policy preferences to an importance placed on leadership strength), which helps explain support for a candidate whose rhetoric and actions were often antithetical to evangelical Christianity. There is an opportunity for future scholarship to focus on the electoral rhetoric and expressed motivations of evangelical leaders, but the current movement of taking a more holistic approach to evangelical voting behavior is a step towards understanding what drives the electoral decision making of this key bloc.

The fact that 81 percent of evangelical Christians voted for Donald Trump suggests there is little division among members of this movement. That James Dobson, Mark Burns, Paula White, and Jerry Falwell, Jr. were all members of Trump's Evangelical Advisory Board, which is responsible for voter outreach and directing policy efforts, indicates that the pattern of coalitionbuilding between leaders of the Religious Right and Republican candidates was continued by Trump's candidacy. While the only two references to partisan unity were made by Mark Burns, it is likely that the party's platform was yet again in line with their policy preferences and that they believed that Trump possessed the strength to push the platform forward. These endorsers demonstrated a pragmatism that values the makeup of the Supreme Court and other issues as much as (or more than) a candidate's morals. However, for the evangelical leaders and groups who opposed the rhetoric and actions of Trump, it was impossible to separate Trump's rhetoric and behavior from their policy preferences. To determine if this apparent schism in the Religious Right's leadership ranks is temporary will require a detailed analysis of evangelicals' electoral rhetoric and behavior in future election cycles. It is possible that Trump's candidacy divided leaders of this movement or that a divide was already present underneath the surface. 
Appendix

\begin{tabular}{|l|c|c|c|c|c|}
\hline Endorser & Dobson & Burns & White & Falwell, Jr. & Total \\
\hline Total Statements* & 9 & 9 & 5 & 8 & $\mathbf{3 1}$ \\
\hline Policy** & 10 & 12 & 2 & 8 & $\mathbf{3 2}$ \\
\hline Partisan*** & 0 & 2 & 0 & 0 & $\mathbf{2}$ \\
\hline Personal**** & 6 & 8 & 9 & 15 & $\mathbf{3 8}$ \\
\hline
\end{tabular}

*Denotes total statements analyzed in this paper.

**Denotes explicit references to policy or legislation preferences.

***Denotes explicit references to partisan loyalty/unity.

****Denotes expressed personal motivations, including qualifications and characteristics. 
Works Cited

“A Declaration by American Evangelicals Concerning Donald Trump.” Change.org. www.change.org/p/donald-trump-a-declaration-by-american-evangelicals-concerningdonald-trump.

Adler, Jerry. "16 People who shaped the 2016 election: Pastor Mark Burns." Yahoo News. 24

Oct. 2016. www.yahoo.com/news/16-people-who-shaped-the-2016-election-pastor-markburns-171839357.html. Accessed 30 Jan. 2017.

Ambrosino, Brandon. "How Trump is Dividing Jerry Falwell's University." Politico. 27 Oct. 2016. www.politico.com/magazine/story/2016/10/trump-evangelical-falwell-libertyuniversity-christian-conservatives-214394. Accessed 30 Jan. 2017.

Anderson, Nick. "For Many at Liberty University, Guns and God Go Hand in Hand." The Washington Post. 14 Dec. 2015. www.washingtonpost.com/local/education/for-many-atliberty-university-guns-and-god-go-hand-in-hand/2015/12/14/3251bfb2-9fc9-11e5-a3c5c77f2cc5a43c_story.html?utm_term=.d1803dd3eb04. Accessed 30 Jan. 2017.

“Awards and Endorsements." Paulawhite.org. http://paulawhite.org/awards-endorsements/. Accessed 30 Jan. 2017.

Banwart, Doug. "Jerry Falwell, the Rise of the Moral Majority, and the 1980 Election.” Western Illinois Historical Review, Vol. V (Spring 2013): 133-157. Web. Accessed 30 Jan. 2017. Blake, Aaron. "Three dozen Republicans have now called for Donald Trump to drop out." The Washington Post. 09 Oct. 2016. www.washingtonpost.com/news/thefix/wp/2016/10/07/the-gops-brutal-responses-to-the-new-trump-video-brokendown/?utm_term=.760dc5eb4732. Accessed 30 Jan. 2017.

Burke, Daniel. “Trump's spiritual adviser, Paula White, fires back at critics.” CNN. 5 Jan. 2017. 
http://www.cnn.com/2017/01/05/politics/paula-white-critics/index.html. Accessed 30 Jan. 2017.

Corasaniti, Nick. "Bernie Sanders Makes Rare Appeal to Evangelicals at Liberty University." The New York Times. 14 Sept. 2015. https://www.nytimes.com/politics/firstdraft/2015/09/14/bernie-sanders-makes-rare-appeal-to-evangelicals-at-libertyuniversity/?_r=0. Accessed 30 Jan. 2017.

Craig Garthwaite and Timothy Moore. "Can Celebrity Endorsements Affect Political Outcomes?

Evidence from the 2008 US Democratic Presidential Primary." Journal of Law, Economics, and Organization 29.2 (2012): 355-84. Web. Accessed 30 Jan. 2017.

Thomas Cronin and Michael Genovese. The Paradoxes of the American Presidency. Oxford: Oxford U Press, 2013. Print.

David Fahrenthold and Katie Zezima. "Ted Cruz: 'I am running for president of the United States'." The Washington Post. 23 Mar. 2015. www.washingtonpost.com/news/postpolitics/wp/2015/03/23/ted-cruz-announces-presidential-run/?utm_term=.3163d30a537f. Accessed 30 Jan. 2017.

@DrJamesCDobson. https://twitter.com/DrJamesCDobson.

Dias, Elizabeth. “Donald Trump's Prosperity Preachers.” TIME Magazine. http://time.com/donald-trump-prosperity-preachers/. Accessed Jan. 302017.

Dias, Elizabeth. “James Dobson Endorses Donald Trump.” TIME Magazine. 21 Jul. 2016. http://time.com/4418163/donald-trump-james-dobson-evangelicals/. Accessed 30 Jan. 2017.

Dobson, James. “Dr. Dobson’s October Newsletter.” October 2016. 
www.drjamesdobson.org/news/commentaries/archives/2016-newsletters/octobernewsletter-2016. Accessed 30 Jan. 2017.

Dobson, James. “Dr. James Dobson on Donald Trump's Christian Faith.” Drjamesdobson.org. http://drjamesdobson.org/news/dr-james-dobson-on-trumps-christian-faith. Accessed 30 Jan. 2017.

Dobson, James. "From Dr. James Dobson - September 1998." http://ontology.buffalo.edu/smith/clinton/character.html. Accessed 03 Feb. 2017. Dobson, James. "Mitt Romney: Talk About Moral Issues... Or Lose.” WorldNetDaily. 15 Aug. 2012. www.wnd.com/2012/08/mitt-romney-talk-about-moral-issues-or-lose/. Accessed 30 Jan. 2017.

Dobson, James. "My Battle with Christian Media About Trump." WorldNetDaily. 3 August 2016. http://www.wnd.com/2016/08/my-battle-with-christian-media-about-trump/. Accessed 14 Feb. 2017.

Elizabeth Dias and Diane Tsai. "Meet Donald Trump's Top Pastor.” TIME Magazine. http://time.com/trump-pastor/. Accessed 30 Jan. 2017.

Fahrenthold, David. "Trump recorded having extremely lewd conversation about women in 2005.” The Washington Post. 08 Oct. 2016. www.washingtonpost.com/politics/trumprecorded-having-extremely-lewd-conversation-about-women-in2005/2016/10/07/3b9ce776-8cb4-11e6-bf8a3d26847eeed4_story.html?utm_term=.a08bd08c3468. Accessed 30 Jan. 2016.

Falwell, Jr., Jerry. “Jerry Falwell Jr: Here's the backstory of why I endorsed Donald Trump.” 
The Washington Post. 27 Jan. 2016. www.washingtonpost.com/news/acts-offaith/wp/2016/01/27/jerry-falwell-jr-heres-the-backstory-of-why-i-endorsed-donaldtrump/?utm_term=.8f2cbd2945b2. Accessed 30 Jan. 2017.

"Falwell Jr.: I'm voting for Trump, despite allegations." CNN. www.cnn.com/videos/politics/2016/10/13/jerry-falwell-jr-vote-for-trump-sot-erin.cnn.

Falwell, Jr., Jerry. “Jerry Falwell Jr.: Trump is the Churchillian leader we need." The Washington Post. 19 Aug. 2016. www.washingtonpost.com/opinions/jerry-falwell-jr-trump-isthe-churchillian-leader-we-need/2016/08/19/b1ff79e0-64b1-11e6-be4e23fc4d4d12b4_story.html?utm_term=.0681b1cd534d. Accessed 30 Jan. 2017.

“Family Talk Mission Statement.” Dr. James Dobson's Family Talk. http://drjamesdobson.org/about/Statement-of-Faith.. Accessed 30 Jan. 2017.

"Focus on the Family." About Focus on the Family. Focus on the Family. www.focusonthefamily.com/about. 30 Jan. 2017.

Fox News Sunday, uploaded on 25 Dec. 2016. www.facebook.com/FoxNewsSunday/videos/10153551710887168/.

"Full Speech: Jerry Falwell, Jr. Speaks at Republican National Convention.” Youtube, uploaded by Right Side Broadcasting. 21 July 2016. https://www.youtube.com/watch?v=VYz_Zyg7uGI.

Glueck, Katie. “Donald Trump’s God whisperer.” Politico. 11 July 2016. www.politico.com/story/2016/07/donald-trump-pastor-paula-white-225315. Accessed 30 Jan. 2017.

Goodstein, Laurie. "Conservative Christian Leader Accuses Republicans of Betrayal.” The New 
York Times. 12 Feb. 1998. 21. www.nytimes.com/1998/02/12/us/conservative-christianleader-accuses-republicans-of-betrayal.html. Accessed 30 Jan. 2017.

Gorski, Philip S. "Conservative Protestantism in the United States?: Toward a Comparative and Historical Perspective.” Evangelicals and Democracy in America, Volume 1: Religion and Society, Edited by Steven Brint and Jean Reith Schroedel, Russell Sage Foundation, 2009, pp. 74-114.

Hillyard, Vaughn. “Pence Cancels Event, Says He's 'Offended' by Trump Comments.” NBC News. 08 Oct. 2016. www.nbcnews.com/politics/2016-election/mike-pence-stands-aftertrump-disinvited-n662436. Accessed 30 Jan. 2017.

Horton, Michael. "Evangelicals should be deeply troubled by Donald Trump's attempt to mainstream heresy." The Washington Post. 3 Jan. 2017. www.washingtonpost.com/news/acts-of-faith/wp/2017/01/03/evangelicals-should-bedeeply-troubled-by-donald-trumps-attempt-to-mainstreamheresy/?utm_term=.338a8e62a34c. Accessed 30 Jan. 2017.

Interview by CT Editors. “James Dobson: Why I Am Voting for Donald Trump.” Christianity Today. 23 Sept. 2016. www.christianitytoday.com/ct/2016/october/james-dobson-why-iam-voting-for-donald-trump.html. Accessed 30 Jan. 2017.

“Invocation by Pastor Paula White.” CNN. 20 Jan. 2017. www.cnn.com/2017/01/20/politics/donald-trump-inauguration-paula-white/.. Accessed 30 Jan. 2017.

Jeltsen, Melissa. Trump's Backwards Views On Parenting Could Have Disastrous Implications.” 
The Huffington Post. 29 Jun. 2016. www.huffingtonpost.com/entry/trumps-backwardsviews-on-parenting-are-dangerous-af_us_57717819e4b017b379f6d602. Accessed 30 Jan. 2016.

Jessica Martínez and Gregory Smith. "How the faithful voted: A preliminary 2016 analysis." Pew Research Center. 09 Nov. 2016. www.pewresearch.org/fact-tank/2016/11/09/howthe-faithful-voted-a-preliminary-2016-analysis/. Accessed 30 Jan. 2017.

Kate Shellnutt and Sarah Eekhoff Zylstra. “Who’s Who of Trump's 'Tremendous' Faith Advisers." Christianity Today. 22 June 2016. www.christianitytoday.com/ct/2016/juneweb-only/whos-who-of-trumps-tremendous-faith-advisors.html. Accessed 30 Jan. 2017.

Kellstedt, Lyman A., et al. "Religious Voting Blocs in the 1992 Election: The Year of the Evangelical?" Sociology of Religion, Vol. 55, No. 3 (1994): 307-326.

Kirkpatrick, David. "Evangelical Leader Threatens to Use His Political Muscle Against Some Democrats." The New York Times. 01 Jan. 2005. www.nytimes.com/2005/01/01/politics/evangelical-leader-threatens-to-use-his-politicalmuscle-against.html?_r=0. Accessed 30 Jan. 2017.

Kuruvilla, Carol. "Why These Evangelical Leaders Are Firmly Against Trump." The Huffington Post. 22 July 2016. 7. www.huffingtonpost.com/entry/why-these-evangelical-leaders-arefirmly-against-trump_us_578d0d14e4b0fa896c3f6fc2. Accessed 30 Jan. 2017.

Langer, Gary, and Jon Cohen. "Voters and Values in the 2004 Election." The Public Opinion Quarterly, vol. 69, no. 5, 2005, pp. 744-759.

“Liberty United Against Trump.” https://docs.google.com/forms/d/e/1FAIpQLScdLe5fbVw0d12MtiYcJCfhLDjpr7AdiYTIkMBttqdLuTQbg/viewform. Accessed 30 Jan. 2017. 
Moore, Russell. "Donald Trump is Not the Moral Leader We Need.” National Review. 22 Jan. 2016. www.nationalreview.com/article/430119/donald-trump-russell-moore-not-moralleader. Accessed 30 Jan. 2017.

Nazworth, Napp. "Paula White on Donald Trump's Christian Faith (Exclusive Interview)." The Christian Post. 8 July 2016. www.christianpost.com/news/paula-white-on-donaldtrumps-christian-faith-exclusive-interview-166205/. Accessed 30 Jan. 2017.

Nickolas, Mark. “James Dobson Calls McCain An Unethical Adulterer, Compares Him To Bill Clinton.” The Huffington Post. 20 Sept. 2008. www.huffingtonpost.com/marknickolas/dobson-calls-mccain-uneth_b_120112.html. Accessed 30 Jan. 2017.

Novacic, Ines. "Why some African-American evangelicals are playing the Trump card.” CBS News. 19 Feb. 2016. www.cbsnews.com/news/why-some-african-american-evangelicalsare-playing-the-trump-card/. Accessed 30 Jan. 2017.

Paige Cutler, Alexander Forbes, and Dustin Wahl. "Liberty University students: Trump is the antithesis of Christian values." The Washington Post. 25 Oct. 2016. www.washingtonpost.com/opinions/liberty-university-students-trump-is-the-antithesisof-christian-values/2016/10/25/3b90630a-9a08-11e6-b3c9f662adaa0048_story.html?utm_term=.9c1819a3e26a. Accessed 30 Jan. 2017.

@pastormarkburns. https://twitter.com/pastormarkburns.

“Pastor Mark Burns Defends Controversial Tweet.” Meet the Press Daily, uploaded on 29 Aug. 2016. www.msnbc.com/mtp-daily/watch/pastor-mark-burns-defends-controversialtweet-753879107657.

"Pastor Mark Burns Gives Benediction at Republican National Convention in Cleveland." 
Youtube, uploaded by Right Side Broadcasting. 18 July 2016.

www.youtube.com/watch?v=HruL3hLaAaU.

Pulliam Bailey, Sarah. “'Still the best candidate': Some evangelicals still back Trump despite lewd video." The Washington Post. 08 Oct. 2016. www.washingtonpost.com/news/actsof-faith/wp/2016/10/08/still-the-best-candidate-some-evangelicals-still-back-trumpdespite-lewd-video/?utm_term=.af7f39be13a6. Accessed 30 Jan. 2017.

Pulliam Bailey, Sarah. “'We're all sinners': Jerry Falwell Jr Defends Donald Trump after video lewd remarks.” The Washington Post. 10 Oct. 2016. www.washingtonpost.com/news/acts-of-faith/wp/2016/10/10/jerry-falwell-jr-the-gopestablishment-could-be-behind-donald-trump-video-leak/?utm_term=.44bbc53f118f. Accessed 30 Jan. 2017.

Randall Balmer, et al. "Forum: Studying Religion in the Age of Trump." Religion and Culture: A Journal of Interpretation. Vol. 27, Issue 1 (2017): 2-57.

Robert Costa and Jenna Johnston. "Evangelical leader Jerry Falwell Jr. endorses Trump.” The Washington Post. 26 Jan. 2016. www.washingtonpost.com/news/postpolitics/wp/2016/01/26/evangelical-leader-jerry-falwell-jr-endorsestrump/?utm_term=.45f23cd97094. Accessed 30 Jan. 2017.

Rodriguez, Sarah. "Falwell Speaks.” Liberty Champion. 8 Mar. 2016. www.liberty.edu/champion/2016/03/falwell-speaks/. Accessed 30 Jan. 2017.

Ross, Ashley. “Donald Trump Says He'd ‘Take Out' Terrorists' Families.” TIME. 02 Dec. 2015. time.com/4132368/donald-trump-isis-bombing/. Accessed 30 Jan. 2017.

Scott, Eugene. “Trump believes in God, but hasn’t sought forgiveness.” CNN. 18 July 2015. www.cnn.com/2015/07/18/politics/trump-has-never-sought-forgiveness/. 
Accessed 30 Jan. 2017.

Shapiro, T. Rees. “Gun-friendly Liberty University to open on-campus shooting range.” The Washington Post. 15 Dec. 2016. www.washingtonpost.com/news/gradepoint/wp/2016/12/15/gun-friendly-liberty-university-to-open-on-campus-shootingrange/?utm_term=.8720e31de41b. Accessed 30 Jan. 2017.

Showalter, Brandon. "Paula White: Donald Trump More 'Hungry for God' Than People Know." The Christian Post. 15 Aug. 2016. www.christianpost.com/news/paula-white-donaldtrump-hungry-for-god-167983/. Accessed 30 Jan. 2017.

Smith, Candace. "Meet the Pastors Who Support Donald Trump.” ABC News. 14 April 2016. abcnews.go.com/Politics/meet-pastors-support-donald-trump/story?id=38406350. Accessed 30 Jan. 2017.

Smith, Samuel. “James Dobson Endorses Donald Trump for President.” The Christian Post. 21 July 2016. www.christianpost.com/news/james-dobson-endorses-donald-trump-forpresident-166827/. Accessed 30 Jan. 2017.

"Social Issues." Focus on the Family. www.focusonthefamily.com/socialissues. Accessed 30 Jan. 2017.

Sonmez, Felicia. "Focus on Family founder James Dobson endorses Rick Santorum.” 19 Jan. 2012. www.washingtonpost.com/blogs/election-2012/post/focus-on-family-founderjames-dobson-endorses-rick-. Accessed 30 Jan. 2017.

Steven G. Brint, and Jean Reith Schroedel. Evangelicals and Democracy in America. New York: Russell Sage Foundation (2009): 76-78. Print.

Tatum, Sophie. "Trump surrogate admits falsifying biographical claims.” CNN. 03 Sept. 2016. 
www.cnn.com/2016/09/03/politics/mark-burns-donald-trump-interview/. Accessed 30 Jan. 2017.

Thomas Carsey and Geoffrey Layman. "Changing Sides or Changing Minds? Party Identification and Policy Preferences in the American Electorate.” Blackwell Publishing, Inc. American Journal of Political Science, Volume 50, Issue 2 (April 2006): 464-477.

"Transcript: Donald Trump's Taped Comments About Women." The New York Times. 08 Oct. 2016. www.nytimes.com/2016/10/08/us/donald-trump-tape-transcript.html?_r=0. Accessed 30 Jan. 2017.

“Trump surrogate confronted about faked biographical claims.” Youtube, uploaded by CNN. 3 Sept. 2016. www.youtube.com/watch?v=rbIGBCcfKZg.

Wallis, Jim. "It's Embarrassing to Be an Evangelical This Election." The Huffington Post. 26 February 2016. www.huffingtonpost.com/jim-wallis/its-embarrassing-to-bean_b_9326650.html._Accessed 30 Jan. 2017.

Wead, Doug. "The Spirituality of George W. Bush.” Frontline: The Jesus Factor. Public Broadcasting Station. www.pbs.org/wgbh/pages/frontline/shows/jesus/president/spirituality.html. Accessed Jan. 30. 2017.

"Why Oprah Endorsed Barack Obama." Oprah.com. www.oprah.com/world/why-oprahendorsed-barack-obama.

Williams, Daniel. God's Own Party: the making of the Christian right. Oxford: Oxford U Press, 2010. Print. 